\title{
In vitro apoptosis induction ability of methanolic extract of Paramignya trimera root (Xao tam phan) in breast cancer stem cells
}

\author{
Sinh Truong Nguyen ${ }^{1,2}$, Le Van Manh Hung ${ }^{1}$, Nguyen Thi Thanh Mai ${ }^{3}$, Nguyen Trung Nhan ${ }^{3}$, \\ Nguyen Xuan Hai ${ }^{3}$, Ngoc Kim Phan ${ }^{1}$, Kiet Truong Dinh ${ }^{4}$, Phuc Van Pham ${ }^{1,2,5, *(1)}$
}

${ }^{1}$ Stem Cell Institute, VNUHCM

University of Science, Ho Chi Minh City, Viet Nam

${ }^{2}$ Laboratory of Cancer Research, VNUHCM University of Science, Ho Chi Minh City, Viet Nam

${ }^{3}$ Faculty of Chemistry, VNUHCM University of Science, Ho Chi Minh City, Viet Nam

${ }^{4}$ Medical Genetic Institute, Ho Chi Minh City, Viet Nam

${ }^{5}$ Laboratory of Stem Cell Research and Application, VNUHCM University of Science, Ho Chi Minh City, Viet Nam

Correspondence

Phuc Van Pham, Stem Cell Institute, VNUHCM University of Science, Ho Chi Minh City, Viet Nam

Laboratory of Cancer Research, VNUHCM University of Science, Ho Chi Minh City, Viet Nam

Laboratory of Stem Cell Research and Application, VNUHCM University of Science, Ho Chi Minh City, Viet Nam

Email: pvphuc@hcmuns.edu.vn

History

- Received: 15 April 2019

- Accepted: 17 July 2019

- Published: 20 Aug 2019

DOI :

https://doi.org/10.15419/bmrat.v6i8.559

\section{Check for updates}

\section{Copyright}

(c) VNU-HCM Press. This is an openaccess article distributed under the terms of the Creative Commons Attribution 4.0 International license.

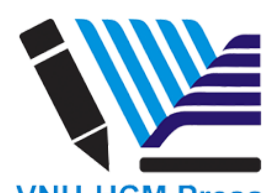

\begin{abstract}
Objective: Cancer has been considered as one of the world's leading causes of death. Recently, the Paramignya trimera plant, locally called "Xao Tam Phan", has become a popular Vietnamese medicinal herb that is used as alternative medicine for cancer treatment support with minimal side effects. In this study, we aimed to demonstrate the cytotoxicity of methanolic extract of Paramignya trimera on a Vietnamese breast cancer stem cell line (VNBRCA1) in vitro. Methods: We used the MTT assay to determine the cytotoxicity of the extract on VNBRCA1 cells and human fibroblast (HF) cell line was used as a control for the plant extract treatment. Clinically used anticancer drug, doxorubicin, was used as a control drug (for relative comparison to the plant extract) to evaluate the selective cytotoxicity of the plant extract on VNBRCA1 and HF cells. We examined the apoptosis induction by the plant extract on VNBRCA1 by Annexin V/7AAD staining and flow cytometry analysis. In addition, the morphology of apoptotic nuclei of treated cells was observed by fluorescent microscopy using double fluorescent staining: Hoechst 33342 and propidium iodide (PI). Results: In comparison between the cytotoxicity of the plant extract and Doxorubicin on both cell lines (VBRCA1 and HF), we observed that plant extract was selectively cytotoxic against VNBRCA1 with an IC50 value of $106 \pm 10 \mu \mathrm{g} / \mathrm{mL}$, while Doxorubicin was discriminatorily cytotoxic against HF with an IC50 value of $0.135 \pm 0.09 \mu \mathrm{g} / \mathrm{mL}$. We also found that the plant extract induced apoptosis VNBRCA1 in a dose-dependent manner. In addition, fluorescent microscopy revealed disintegrated nuclei of plant extract-treated cells, representing a hallmark of apoptosis. Conclusions: These results showed that Paramignya trimera methanolic extract selectively killed VNBRCA1 cell lines, indicating that Paramignya trimera methanolic extract may represent a potential agent for cancer treatment.
\end{abstract}

Key words: Selective, anticancer, Paramignya trimera, Vietnamese breast cancer cell (VNBRCA1), apoptosis

\section{INTRODUCTION}

The treatment of cancer has many challenges due to factors such as the effectiveness of therapies, tumor recurrence, and side effects of current therapies (including surgery, radiotherapy, and chemotherapy). Among the cancer types, breast cancer is the one of the leading causes of death worldwide. In 2012, there were nearly 1.7 million cases diagnosed and 522,000 deaths worldwide ${ }^{1}$. In Vietnam, in 2008, breast cancer occupied the highest proportion of all types of cancer: $29.7 \%$ in Hanoi and $19.4 \%$ in Ho Chi Minh City $^{2}$. In 2003, Al-hajj and his team discovered that breast cancer stem cells with $\mathrm{CD} 44^{+} \mathrm{CD} 24^{-/ \text {low }}$ expression could initiate tumor formation and play an important role in metastasis as well as tumor recurrence $^{3}$. Thus, it would be potentially beneficial to alternatively or additionally treat cancer by attacking the cancer stem cells.
For a long period of time in human history, natural plants have been used as useful remedies in a variety of aspects, such as for antimicrobial, anti-inflammatory, and anti-carcinogenic applications. To solve the health problems caused by cancer diseases nowadays, it is necessary for scientists to search for potential anticancer compounds from natural resources. The strategy for this drug development starts with the investigation of the effects of plant extracts on different cancer cell lines to identify the potential targets. This approach has been used to identify many clinically used anticancer agents in the past. Indeed, more than $60 \%$ of currently available drugs are natural compounds or structually related to them ${ }^{4}$. For instance, Podophyllotoxin is the most abundant lignan of Podophyllin isolated from species of genera Podophyllum, Camptothecin is a quinolone alkaloid with antitumor property derived from Camptoteca acuminata $^{5,6}$, and Paclitaxel (Taxol ) is a diteprene 
with a taxane nucleus extracted from Taxus brevifo$\operatorname{lia}^{7,8}$.

Paramignya trimera (P. trimera) plant, called "Xao tam phan" in Vietnamese, has been used as medicinal plant for supporting cancer treatment in patients. Paramignya trimera, which belongs to Paramignya genus and Rutaceae family, is an endemic plant of Vietnam and Thailand. In Vietnam, P. trimera is mostly distributed in the southern part of the country. Several diseases have been reported to benefit from $P$. trimera plant extract. A recent study demonstrated that the crude methanolic extract of $P$. trimera has hepatoprotective and anticancer activity. Ostruthin was discovered to be a major compound in P. trimera roots and stems ${ }^{9}$, and it was also demonstrated to be cytotoxic against pancreatic cancer cells ${ }^{10}$. In addition to ostruthin, several studies have identified some new coumarins which were shown to be promising and to have novel bioactivity ${ }^{11}$. For these reasons, we hypothesize that $P$. trimera might have cytotoxicity against breast cancer stem cells.

In this study, we investigated the effect of $P$. trimera plant on breast cancer stem cells (VNBRCA1) in vitro. VNBRCA1 was isolated from the breast tumor of a Vietnamese patient by the Stem Cell Research and Application Laboratory in a previous study, and has stem cell-like properties ${ }^{12}$. We sought to investigate the selective killing ability and the mode of cell death caused by $P$. trimera on VNBRCA1.

\section{METHODS}

\section{Cell lines}

VNBRCA1 cell line was isolated from a Vietnamese patient in 2012 by the Laboratory of Stem Cell Research and Application, University of Sciences, Ho Chi Minh City. VNBRCA1 was characterized by $\mathrm{CD} 44^{+} \mathrm{CD} 24^{-/ \text {low }}$ phenotype and had the ability to initiate tumorigenesis in vivo ${ }^{13}$. Human fibroblasts (HF) were isolated from human skin collected from patients at Gia Dinh Hospital with signed consent. The use of skin sample were approved by the Institutional Ethical Committee (Stem Cell Institute, VNUHCM University of Sciences). The VNBRCA1 and HF cells were cultured in $25 \mathrm{~cm}^{2}$ flasks with DMEM/F12 (Sigma-Aldrich, St. Louis, MO, USA) supplemented with $10 \%$ fetal bovine serum (FBS) (SigmaAldrich) and $1 \%$ penicillin/streptomycin antibiotic (ThermoFisher Scientific, Waltham, MA, USA) in a $\mathrm{CO}_{2}$ incubator (Binder, Germany) with an atmosphere of $95 \%$ air, $5 \% \mathrm{CO}_{2}$ at $37^{\circ} \mathrm{C}$.

\section{Collection of plant material}

The plant was collected at Ma Da forest in Dong Nai Culture and Nature Reserve of Dong Nai Province, Vietnam in April 2014. The plant was identified by Assoc. Ph.D. Hop Tran, Institute of Tropical Biology, Ho Chi Minh City, Vietnam. The voucher sample (MCE018) was preserved in the Division of Medicinal Chemistry, Faculty of Chemistry, University of Science, Viet Nam National University- Ho Chi Minh City, Viet Nam.

\section{Extraction of plant material}

The dried root of $P$. trimera plant ( $200 \mathrm{~g}$ ) was cut into small pieces and extracted with $\mathrm{MeOH}(300 \mathrm{~mL}$, reflux, $3 \mathrm{~h} \times 3)$. The $\mathrm{MeOH}$ solution was evaporated under reduced pressure to yield the $\mathrm{MeOH}$ extract (15 g).

\section{Treatment of Doxorubicin and Paramignya trimera methanolic extract}

Cells were cultured in medium with different concentrations of Doxorubicin (Sigma-Aldrich) and $P$. trimera extract for $48 \mathrm{~h}$ and $72 \mathrm{~h}$, respectively. Briefly, after one day of pre-incubation for the attachment of VNBRCA1 cells to the culture surface, cells were treated with Doxorubicin at the concentration of $1000,500,250,125,75,32.5,16,8$, or $0(\mu \mathrm{g} / \mathrm{mL})$. At the same time, cells were also treated with $P$. trimera extract at $200,100,50,25,12.5,6,3,1.5$, or $0(\mathrm{mg} / \mathrm{mL})$. Each concentration was tested in triplicate. Cell viability was measured by MTT assay. Each experiment was repeated three times. The data were analyzed by GraphPad Prism (GraphPad Software, Inc., La Jolla, CA, USA).

\section{Determination of IC $_{50}$ value by MTT assay}

After cells were treated with chemotherapeutic agents, MTT (3-(4, 5-dimethylthiazolyl-2)-2, 5diphenyltetrazolium bromide) assay was performed to determine the $\mathrm{IC}_{50}$ value of Doxorubicin and $P$. trimera extract. Briefly, MTT agent was added into each well on the second day of Doxorubicin treatment and on the third day of plant extract treatment. Then, the plates were incubated at $37^{\circ} \mathrm{C}$ for $4 \mathrm{~h}$. After that, MTT agent was removed from those wells. During the next step, dimethyl sulfoxide (DMSO) was added to wells and incubated for $15 \mathrm{~min}$ at $37^{\circ} \mathrm{C}$. The OD value at $595 \mathrm{~nm}$ wavelength was measured by DTX880 machine (Beckman Coulter, USA). The $\mathrm{IC}_{50}$ was determined based on the dose-response curve. The X-axis of the dose-response curve was the 
logarithm of the different concentrations of the agent, and the Y-axis is the inhibition percentage calculated from the OD value. From this sigmoidal curve, $\mathrm{IC}_{50}$ (X value) was calculated by setting $\mathrm{Y}$ value as $50 \%$.

\section{Viability staining assay}

Cell viability of VNBRCA1 at $250 \mu \mathrm{g} / \mathrm{mL}$ concentration was evaluated by Hoechst 33342/ PI staining. Skin human fibroblast (HF) cells were used as a control cell line. Briefly, VNBRCA1 and HF cells were treated with $P$. trimera extract at a concentration of $250 \mu \mathrm{g} / \mathrm{mL}$; untreated cells were cultured in normal media complemented with solvent. At day 3 of treatment, cells were stained with Hoechst 33342/ PI. The final concentration of Hoechst 33342, as well as PI, was $1 \mu \mathrm{g} / \mathrm{mL}$ in culture media. Next, cells were incubated in an incubator with the condition of $37^{\circ} \mathrm{C}, 5 \%$ $\mathrm{CO}_{2}$ for 5 minutes. Stained cells were observed under a fluorescent microscope.

\section{Annexin V/ 7-AAD staining analysis by flow cytometry}

The culture flask of VNBRCA1 was treated with $P$. trimera extract at 3 concentrations of 30,60 and 125 $\mu \mathrm{g} / \mathrm{mL}$, for 3 days. After that, annexin V/7-AAD staining and flow cytometry techniques were performed to determine the mode of cell death. Briefly, all cells were detached from the flask surface by trypsin and centrifuged at $300 \mathrm{~g}$ to collect the pellet. After that, cells were stained with annexin-V-FITC and 7-AAD. Stained cells were analyzed by a BD FACSCalibur (BD Biosciences, San Jose, CA, USA) flow cytometer. Data was analyzed by CellQuest Pro software.

\section{Statistical analysis}

Data was analyzed by Graphpad Prism software (Graphpad Software Inc.) for the determination of IC50 value. All data were presented as the mean of triplicate experiments. Statistically significant difference was set as $\mathrm{p}<0.05$.

\section{RESULTS}

\section{Selective cytotoxic effect of $P$. trimera against VNBRCA1}

After 3 days of treatment with 10 different concentrations of $P$. trimera extract $(2000,1000,500,250,125$, $62.5,31.25,15.63,7.81$, or $3.91 \mu \mathrm{g} / \mathrm{mL}$; control), proliferation of $P$. trimera extract-treated cells was measured by MTT assay. The $\mathrm{IC}_{50}$ value of $P$. trimera extract on VNBRCA1 after $72 \mathrm{~h}$ was $106 \pm 10 \mu \mathrm{g} / \mathrm{mL}$, while $\mathrm{IC}_{50}$ of $P$. trimera extract on $\mathrm{HF}$ after $72 \mathrm{~h}$ was $310 \pm 8 \mu \mathrm{g} / \mathrm{mL}$ (Figure 1).

Similar to the method for calculating the $\mathrm{IC}_{50}$ of $P$. trimera extract, the OD value was measured to evaluate the dose-response inhibition of Doxorubicin (1, $0.5,0.25,0.125,0.0625,0.031,0.016$, or $0(\mu \mathrm{g} / \mathrm{mL})$ on VNBRCA1 and on HF cells. The $\mathrm{IC}_{50}$ value of Doxorubicin on VNBRCA1 after $48 \mathrm{~h}$ is $0.63 \pm 0.12 \mu \mathrm{g} / \mathrm{mL}$ while $\mathrm{IC}_{50}$ value of Doxorubicin on $\mathrm{HF}$ after $48 \mathrm{~h}$ was $0.135 \pm 0.09 \mu \mathrm{g} / \mathrm{mL}$.

Based on the IC50 value of each agent on both VNBRCA1 and HF, we determined the selectivity index (SI). This parameter reflects the selective toxicity of the agent against cancer cell but not normal cells. In this study, we calculated SI of the agent by the ratio of the $I C_{50}$ of the agent on $\mathrm{HF}$ to the $I C_{50}$ of the agent on VNBRCA1 (Table 1):

SI $=$ IC50 of agent on HF

$\mathrm{SI}=\frac{\mathrm{C} 0 \text { of agent on VNBRCAI }}{\text { IC50 }}$

The higher the SI, the more selective the toxicity of the agent against breast cancer cells (but not HF cells). Calculations of $\mathrm{SI}_{\text {extract }}$ and $\mathrm{SI}_{\text {Doxorubicin }}$ were performed to determine the selective cytotoxicity of both the plant extract and Doxorubicin against VNBRCA1. SI of $P$. trimera extract on HF/VNBRCA1:

SI $_{\text {P.trimera extract }}=\frac{I C 50 \text { of extract on } H F}{I C 50 \text { of extract on } V N B R C A 1}=\frac{310}{106}=$ 2.92

SI of Doxorubicin on HF/VNBRCA1:

$\mathrm{SI}_{\text {Doxorubicin }}=\quad \frac{\text { IC50 of Doxorubicin on } H F}{\text { IC50 of Doxorubicin on } V N B R C A 1}=$ $\frac{0.135}{0.63}=0.21$

Difference between $\mathrm{SI}_{\text {P.trimera extract }}$ and $\mathrm{SI}_{\text {Doxorubicin }}$ $\frac{\text { SI of extract }}{\text { SI of Doxorubicin }}=\frac{2.9292}{0.2121}=13.92$

$\mathrm{SI}_{\text {P. trimera extract }}$ was nearly 14 -fold higher than $\mathrm{SI}_{\text {Doxorubicin }}$.

Hoechst 33342 is a blue-fluorescence dye and PI is a red-fluorescence dye; each has different excitation/emission wavelengths (350/461 nm and 536/617 $\mathrm{nm}$, respectively). Hoechst 33342 can stain the DNA of both dead and living cells while PI is only permeable to dead cells. At a concentration of $250 \mu \mathrm{g} / \mathrm{mL}$, $P$. trimera plant extract caused severe cell death to VNBRCA1 (red spots in Figure 2C), while P. trimera extract did not show toxicity in HF cells (Figure 2 A). This indicated the selective cytotoxic ability of $P$. trimera extract on VNBRCA1 cells.

\section{Paramignya trimera extract induced apop- tosis in VNBRCA1}

The total apoptotic populations (late apoptosis in upper right quadrant and early apoptosis in lower right 

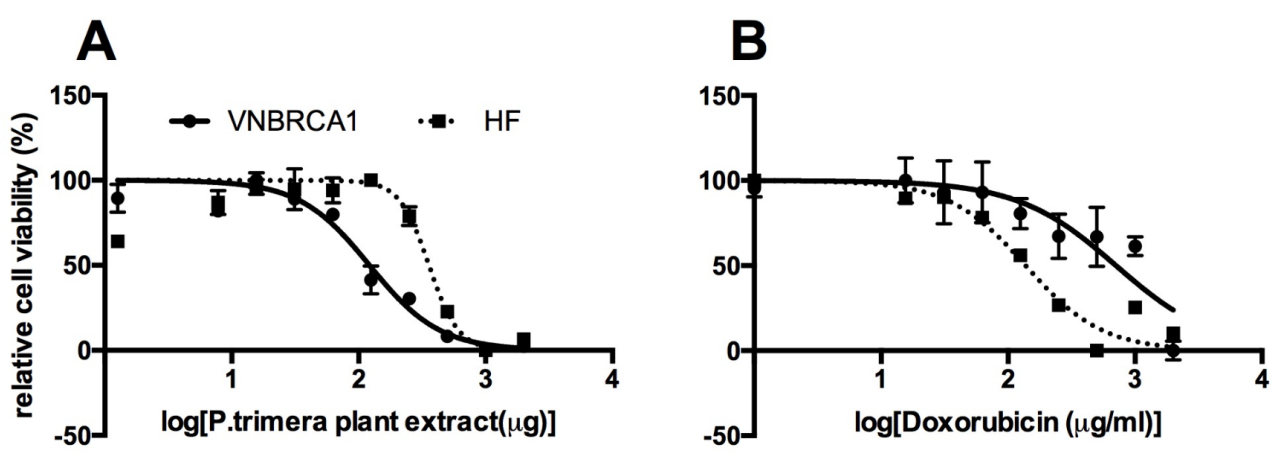

Figure 1: Inhibition curve of $P$. trimera extract and Doxorubicin on both VNBRCA1 and HF cell line. A. The dose-response inhibition curve of HF and VNBRCA1 by P. trimera extract with the concentration 2000, 1000, 500, $250,125,62.5,30,15,0(\mathrm{ug} / \mathrm{mL})$. B. The dose-response inhibition curve of Doxorubicin on VNBRCA1 and HF at the concentrations of $1,0.5,0.25,0.125,0.0625,0.031,0.016$, or $0 \mu \mathrm{g} / \mathrm{mL}$. The viable cells were evaluated by MTT assay after 3 days of treatment. The experiment was repeated three times. The curves represented 3 replications. The data was presented by mean \pm SD.

Table 1: Summary of the $\mathrm{IC}_{50}$ value and the selectivity index (SI)

\begin{tabular}{lccc}
\hline & IC50 on VNBRCA1 & IC50 on HF & SI of VNBRCA1/HF \\
P. trimera extract & $106 \pm 10 \mu \mathrm{g} / \mathrm{ml}$ & $310 \pm 8 \mu \mathrm{g} / \mathrm{ml}$ & 2.92 \\
Doxorubicin & $0.63 \pm 0.12 \mu \mathrm{g} / \mathrm{ml}$ & $0.135 \pm 0.09 \mu \mathrm{g} / \mathrm{ml}$ & 0.214 \\
\hline
\end{tabular}

SI: selectivity index

quadrant) are shown in Figure 3; the \% of apoptosis was $2.98 \%$ (for untreated cells), $4.37 \%$ (for the 30 $\mu \mathrm{g} / \mathrm{mL}$ P. trimera extract sample), $6.99 \%$ (for the 62.5 $\mu \mathrm{g} / \mathrm{mL}$ sample), and $20.97 \%$ (for the $125 \mu \mathrm{g} / \mathrm{mL}$ sample). The results also showed that the apoptosis percentage clearly increased when the concentration of $P$. trimera extract doubled, while the necrotic cell population was tightly augmented from $0.29 \%$ (in control sample) to $10 \%$ (in the $125 \mu \mathrm{g} / \mathrm{mL}$ sample). Viable cells were significantly reduced from $96 \%$ to $78 \%$, in the $125 \mu \mathrm{g} / \mathrm{mL}$ P. trimera extract sample.

We used the plant extract at a concentration of 200 $\mu \mathrm{g} / \mathrm{mL}$, which is nearly double of the IC50 value of the $P$. trimera extract on VNBRCA1 to test effects of the extract on DNA damage. The results showed that the extract caused disintegrated nuclei in VNBRCA1 after $24 \mathrm{~h}$ of treatment, as compared to human fibroblast cells (where the extract did not induce much DNA disintegration) (Figure 4). This confirmed that the P. trimera extract can induce apoptosis in VNBRCA1 cells.

\section{DISCUSSION}

P.trimera has been traditionally used for a long time as a medicinal plant. The cytotoxic effects of $P$. trimera extract on certain cell types (such as Hela and HepG2, but not for VNBRCA1) have been reported in several studies. In this paper, we demonstrated the evidence of selective cytotoxicity of the plant extract against VNBRCA1 cells compared to normal human fibroblast. Furthermore, we provided evidence of the apoptosis-inducing effect of $P$. trimera extract on $\mathrm{VN}$ BRCA1 in vitro.

The results from the MTT assay showed that the $\mathrm{IC}_{50}$ of the P. trimera plant extract on VNBRCA1 was 106 $\mu \mathrm{g} / \mathrm{mL}$, which is about 3 -fold lower than the IC50 value of the $P$. trimera extract on human skin fibroblasts (HF; a non-cancerous cell line), which was 310 $\mu \mathrm{g} / \mathrm{mL}$. This means that the $P$. trimera extract has a 3 -fold stronger killing effect on VNBRCA1 cells than on HF cells. Thus, the $P$. trimera extract killed breast cancer stem cells (VNBRCA1), but had negligible side effects on normal human skin cells. A previous study showed that the methanolic extract of $P$. trimera was active against HepG2 and Hela cell lines with IC50 values of 39.61 and $5.36 \mu \mathrm{g} / \mathrm{mL}$, respectively. The previously reported IC50 values of $P$. trimera on HepG2 and Hela also showed the selective toxicity of the plant extract in comparison to its IC50 value on HF in this study (Figure 1).

Meanwhile, we also investigated the cytotoxicity of Doxorubicin on VNBRCA1 and HF. Interestingly, the 


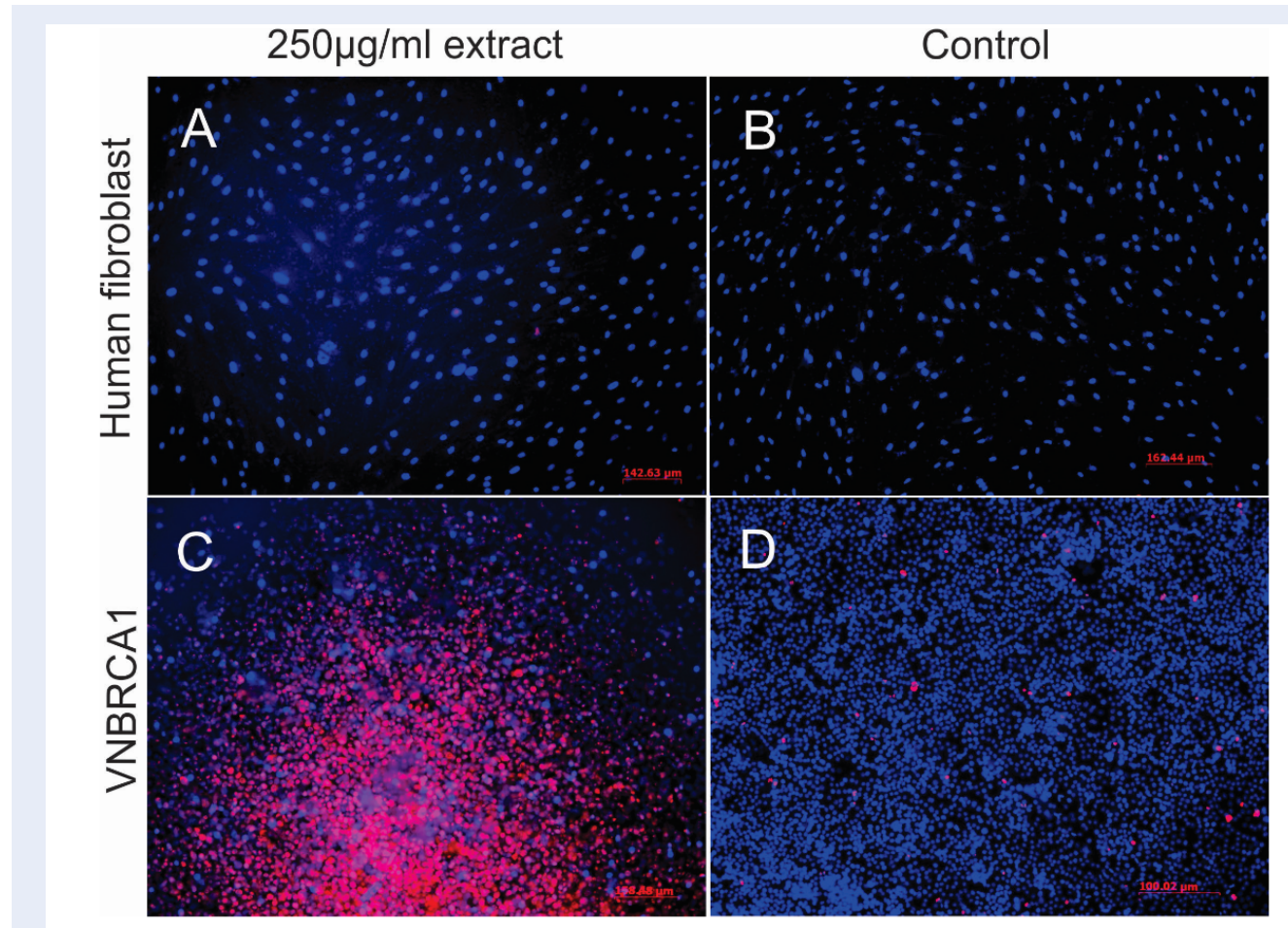

Figure 2: Hoechst 33342/PI- stained viable cells. VNBRCA1 and HF cells were treated with plant extract $P$. trimera at a concentration $250 \mu \mathrm{g} / \mathrm{mL}$. Untreated cells were cultured in normal media. After 3 days, cells were stained with Hoechst 33342/PI at a final concentration of $1 \mu \mathrm{g} / \mathrm{mL}$ for both dyes. The samples were observed under fluorescent microscopy after $10 \mathrm{~min}$ of incubation.

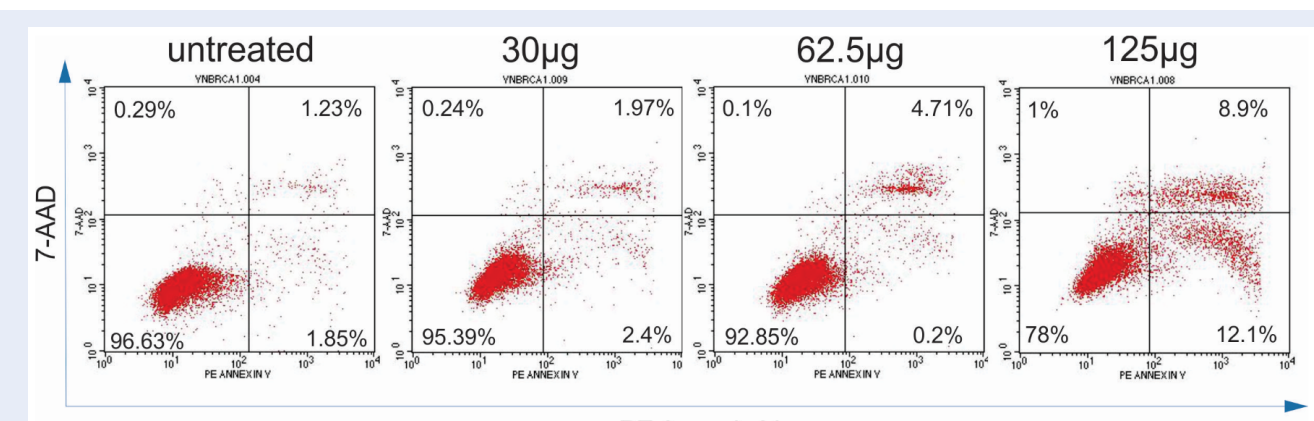

PE Annexin V

Figure 3: Flow cytometry analysis of $P$. trimera extract-treated VNBRCA1 cells. Breast cancer stem cells (VNBRCA1) were treated with P. trimera extract at a concentration of $30,62.5$, or $125 \mu \mathrm{g} / \mathrm{mL}$. The control sample was cultured in normal media supplemented with methanol solvent. After 24 hours of treatment, cells were analyzed by flow cytometry. 


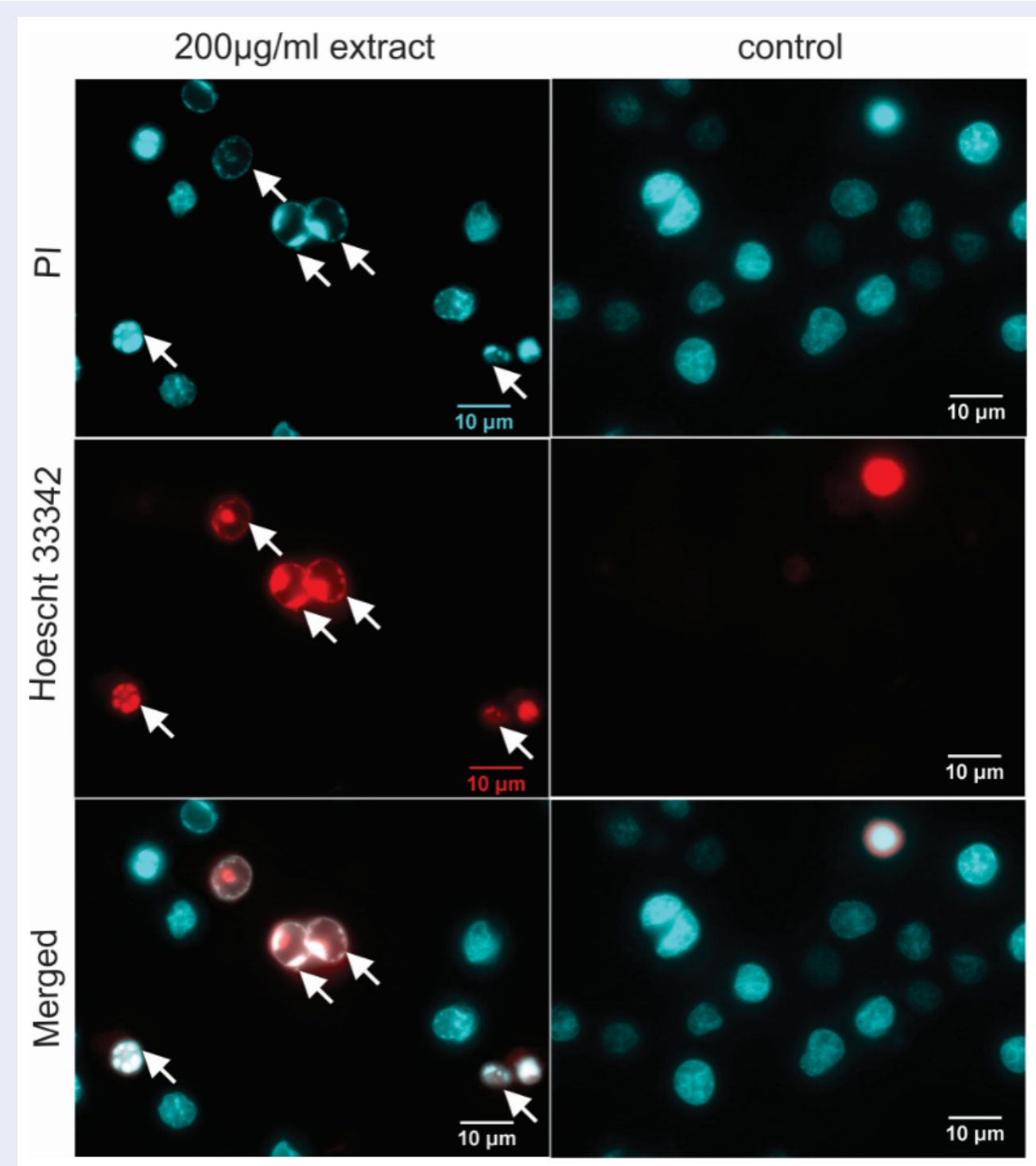

Figure 4: Fluorescent images of disintegrated nuclei of Paramignya trimera extract-treated VNBRCA1 cells. VNBRCA1 cells were treated with plant extract $(200 \mu \mathrm{g} / \mathrm{mL})$. Control cells is VNBRCA1 cells untreated with plant extract, these cells are cultured in normal condition. After 24 hours, cells were detached and co-stained with Hoechst 33342 and PI. Cells were then observed under fluorescent microscopy at 100X magnification. The white arrows indicate disintegrated nuclei.

$\mathrm{IC}_{50}$ of Doxorubicin on $\mathrm{HF}$ was $0.135 \mu \mathrm{g} / \mathrm{ml}$, which was almost 4.5 -fold lower than the $\mathrm{IC}_{50}$ of Doxorubicin on VNBRCA1 $(0.63 \mu \mathrm{g} / \mathrm{mL})$. Thus, Doxorubicin kills more normal cells (HF) than cancer cells (VNBRCA1) (Figure 1).

From the $\mathrm{IC}_{50}$ data from Table 1, we bring up the equation called selectivity index (SI), which is the ratio of (IC50 of the agent on HF)/(IC50 of the agent on VNBRCA1). The selectivity index was previously used to figure out the selective cytotoxic activity of synthesis drugs on human breast carcinoma MCF-7 compared to normal cell line ${ }^{14}$. In this study, the agent could be either $P$. trimera extract or Doxorubicin. The greater the SI value is, the more toxic the agent is against VNBRCA1 (but safer against HF). Therefore, calculations of $\mathrm{SI}_{\text {extract }}$ and $\mathrm{SI}_{\text {Doxorubicin }}$ were performed to compare the selective cytotoxicity of both P. trimera extract and Doxorubicin, on cancer cells (VNBRCA1) and normal cells (HF). The SI of the P.trimera extract was nearly 14 -fold higher than that for Doxorubicin $(2.92>0.214)$. From the above results, it can be concluded that the P.trimera extract not 
only showed less toxicity on HF than on VNBRCA1, but also showed more selective toxicity than Doxorubicin. Because of its considerably high selective cytotoxicity, P.trimera extract could become a potential candidate as an anticancer agent.

Hoechst 33342/ PI staining results indicated that P. trimera extract showed cytotoxicity against $\mathrm{VN}$ BRCA1 but not HF, at the concentration of $250 \mu \mathrm{g} / \mathrm{mL}$ (Figure 2). In other words, at this concentration, the extract was safe on HF, while a large population of VNBRCA1 underwent cell death. Taken together, the data show that $P$. trimera extract primarily displays a highly selective toxicity in cancer cells. However, in order to further examine the side effect index of the $P$. trimera extract, it was necessary to perform the cytotoxicity assay on other normal cell lines, such as non-cancerous breast cell line or normal liver cell line. In recent studies, the side effect index was similarly performed to compare the $\mathrm{IC}_{50}$ value of the agent on non-cancerous breast cell line and cancerous breast cell line ${ }^{15}$, or to determine the $\mathrm{IC}_{50}$ value of the agent on Hep-G2 cell line versus normal liver cell line ${ }^{16}$. PI staining assay further showed the selective cytotoxicity of the $P$. trimera extract on the 2 cell lines, HepG2 and HF, but the result did not indicate whether the $P$. trimera extract induced apoptosis on HepG2 or not. The reason for this is that PI stained both necrotic cells and late apoptotic cells, thus PI staining only could not discriminate the two types of cell death ${ }^{17-19}$.

Apoptosis induction of medicinal plant extract is an important characteristic required in cancer drug screening ${ }^{20}$. It is a more favorable mode of cell death than necrosis since cell death via necrosis can cause inflammation during treatment ${ }^{21}$. Apoptosis is characterized by chromatin condensation, cell membrane shrinkage, and DNA fragmentation. In this study, the apoptotic cell population from $P$. trimera extracttreated cells was firstly analyzed by flow cytometry. VNBRCA1 cells were cultured in medium complemented with $P$. trimera extract, with various concentrations $(30,60$, or $125 \mu \mathrm{g} / \mathrm{mL})$ of $P$. trimera for 24 hours, and then the apoptotic population was identified by Annexin V staining. Meanwhile, the necrotic population was identified by 7 -AAD staining. The results showed that percentage of apoptotic population increased as concentrations of $P$. trimera extract were increased. The early and late apoptotic population was $2.98 \%$ (for untreated sample), $4.37 \%$ (for 30 $\mu \mathrm{g} / \mathrm{mL}$ extract sample), $6.99 \%$ (for $60 \mu \mathrm{g} / \mathrm{mL}$ extract sample), and $20.97 \%$ (for $125 \mu \mathrm{g} / \mathrm{mL}$ extract sample)

(Figure 3). Thus, the apoptosis induced by $P$. trimera extract appears to be dose-dependent.
However, the percentage of necrotic population was not significantly increased. Even at the highest concentration of $P$. trimera extract $(125 \mu \mathrm{g} / \mathrm{mL})$, the necrotic population was only $1 \%$, which was not considerably different from the portion of apoptotic population $(0.29 \%)$ in the control sample. Recently, another study reported the dose-dependent apoptosis of MCF-7 breast cancer cell line treated with $\mathrm{Le}$ pidium sativum seed extract ${ }^{22}$. However, the authors reported that extracts of Lepidium sativum seeds also caused apoptosis in human skin fibroblasts at the same level as that of MCF-7 breast cancer cells. In general, the Lepidium sativum extract did not selectively kill cancer cells in comparison with the $P$. trimera extract. However, in our study, the P. trimera extract was tested only on VNBRCA1 cells and HF cells, so it is necessary to examine the cytotoxicity of this plant extract on other breast cancer cell lines. Based on those results, we can conclusively compare the P. trimera extract with other extracts evaluated in other studies.

Nuclei observation was performed in order to confirm the findings from the flow cytometry results which indicated that the extract had the ability to induce apoptosis. Disintegrated nuclei appeared in the fluorescent images when cells were treated with P. trimera extract, demonstrating that the treated cells underwent apoptosis. On the other hand, only a few dead cells were observed in the control sample and those cells did not show abnormal nuclei. These observations are in agreement with the flow cytometry results which indicating that the extract can induce apoptosis on VNBRCA1 after a short period of incubation.

\section{CONCLUSIONS}

Overall, the results from this study suggest that $P$. trimera methanolic extract could be a potential anticancer agent. MTT assay results and microscopic images indicated that the cytotoxicity of the extract was dose-dependent. The P. trimera extract selectively killed the VNBRCA1 breast cancer cell line but not normal human fibroblast HF. In addition, P. trimera extract was shown to induce apoptosis in VNBRCA1 after a short term of incubation (24 hours). Further studies are warranted to investigate the antitumor properties of $P$. trimera extract in vivo. Identification of bioactivity compounds in $P$. trimera extract is also necessary. In conclusion, $P$. trimera could be a promising anti-proliferative agent against Vietnamese breast cancer cells. 


\section{ABBREVIATIONS}

HF: human fibroblast

P. Trimera: Paramignya trimera

PI: propidium iodide

SI: selectivity index

VNBRCA1: Vietnamese breast cancer stem cell line

\section{COMPETING INTERESTS}

Authors declare no conflict of interest.

\section{AUTHORS' CONTRIBUTIONS}

Sinh and Hung carried out the IC50 study. Sinh helped to perform FCM assay and fluorescent of disintergrated nuclei experiment. Mai, Hai, Nhan participated in performing the extract from Paramignya trimera root. Ngoc and Kiet and Phuc helped to draft the manuscript.

\section{ACKNOWLEDGMENTS}

This research was funded by Vietnam National University, Ho Chi Minh city, Viet Nam under grant number A2015-18-01/HD-KHCN.

\section{REFERENCES}

1. Ferlay J, Soerjomataram I, Dikshit R, Eser S, Mathers C, Rebelo $M$, et al. Cancer incidence and mortality worldwide: sources, methods and major patterns in GLOBOCAN 2012. Int J Cancer. 2015;136(5):359-86. PMID: 25220842. Available from: 10.1002/ijc. 29210.

2. Trieu PD, Mello-Thoms C, Brennan PC. Female breast cancer in Vietnam: a comparison across Asian specific regions. Cancer Biol Med. 2015;12(3):238-45. PMID: 26487968.

3. Al-Hajj M, Wicha MS, Benito-Hernandez A, Morrison SJ, Clarke MF. Prospective identification of tumorigenic breast cancer cells. Proc Natl Acad Sci USA. 2003;100(7):3983-8. PMID: 12629218. Available from: 10.1073/pnas.0530291100.

4. Gordaliza M. Natural products as leads to anticancer drugs. Clin Transl Oncol. 2007;9(12):767-76. PMID: 18158980. Available from: 10.1007/s12094-007-0138-9.

5. Wall ME, Wani MC, Cook CE, Palmer KH, McPhail AT, Sim GA. Plant Antitumor Agents. I. The Isolation and Structure of Camptothecin, a Novel Alkaloidal Leukemia and Tumor Inhibitor from Camptotheca acuminata1,2. J Am Chem Soc. 1966;88(16):3888-90. Available from: 10.1021/ja00968a057.

6. Chavan S, Pathak AB, Kalkote UR. Total synthesis of (+)camptothecin via an intramolecular palladium-catalyzed cyclization strategy. Synlett. 2007;2007(17):3. Available from: 10.1055/s-2007-991054.

7. Kingston DG, Newman DJ. Taxoids: cancer-fighting compounds from nature. Curr Opin Drug Discov Devel. 2007;10(2):130-44. PMID: 17436548.

8. Camidge R. The Story of Taxol: Nature and Politics in the Pursuit of an Anti-Cancer Drug. BMJ. 2001;323(7304):115-115. Available from: 10.1136/bmj.323.7304.115/a.
9. Pham HB. N.M.K., Nguyen T.B.T, Isolation and quantitative analysis of ostruthin in the medicinal plant Paramignya trimera collected in Vietnam. Medicine Master. 2013;18(3):173-9.

10. Li F, Okamura Y, Dibwe DF, Awale S, Kadota S, Tezuka Y. Anti-austerity agents from Rhizoma et Radix Notopterygii (Qianghuo). Planta Med. 2012;78(8):796-9. PMID: 22516931. Available from: 10.1055/s-0031-1298463.

11. Cuong NM, Huong TT, Khanh PN, Tai NV, Ha VT, Son NT, et al. Paratrimerins A and B, Two New Dimeric Monoterpene-Linked Coumarin Glycosides from the Roots and Stems of Paramignya trimera. Chem Pharm Bull (Tokyo). 2015;63(11):945-9. PMID: 26521859. Available from: 10.1248/ cpb.c15-00336.

12. Pham PV, Phan NL, Nguyen NT, Truong NH, Duong TT, Le DV, et al. Differentiation of breast cancer stem cells by knockdown of CD44: promising differentiation therapy. J Transl Med. 2011;9(1):209. PMID: 22152097. Available from: 10.1186/ 1479-5876-9-209.

13. Pham PV, Vu BT, Nhan PLC, Thuy DT, et al. Isolation of Breast Cancer Stem Cells by Single-Cell Sorting. In: Ceccherini-Nelli, Matteoli B, editors. Biomedical tissue culture. Intech Open; 2012. p. 59-72. Available from: $10.5772 / 51506$.

14. Badisa RB, Darling-Reed SF, Joseph P, Cooperwood JS, Latinwo LM, Goodman CB. Selective cytotoxic activities of two novel synthetic drugs on human breast carcinoma MCF-7 cells. Anticancer Res. 2009;29(8):2993-6. PMID: 19661306.

15. Abu N, Akhtar MN, Ho WY, Yeap SK, Alitheen NB. 3-Bromo-1hydroxy-9,10-anthraquinone (BHAQ) inhibits growth and migration of the human breast cancer cell lines MCF-7 and MDAMB231. Molecules. 2013;18(9):10367-77. PMID: 23985955. Available from: 10.3390/molecules180910367.

16. Al-Qubaisi M, Rozita R, Yeap SK, Omar AR, Ali AM, Alitheen NB. Selective cytotoxicity of goniothalamin against hepatoblastoma HepG2 cells. Molecules. 2011;16(4):2944-59. PMID: 21471934. Available from: 10.3390/molecules 16042944 .

17. Brauchle E, Thude S, Brucker SY, Schenke-Layland K. Cell death stages in single apoptotic and necrotic cells monitored by Raman microspectroscopy. Sci Rep. 2014;4(1):4698. PMID: 24732136. Available from: 10.1038/srep04698.

18. Denecker G, Vercammen D, Declercq W, Vandenabeele P. Apoptotic and necrotic cell death induced by death domain receptors. Cell Mol Life Sci. 2001;58(3):356-70. PMID: 11315185. Available from: $10.1007 /$ PL00000863.

19. Kroemer G, Dallaporta B, Resche-Rigon M. The mitochondrial death/life regulator in apoptosis and necrosis. Annu Rev Physiol. 1998;60(1):619-42. PMID: 9558479. Available from: 10.1146/annurev.physiol.60.1.619.

20. Dixon SC, Soriano BJ, Lush RM, Borner MM, Figg WD. Apoptosis: its role in the development of malignancies and its potential as a novel therapeutic target. Ann Pharmacother. 1997;31(1):76-82. PMID: 8997471. Available from: 10.1177/ 106002809703100113.

21. Kiaris H, Schally AV. Apoptosis versus necrosis: which should be the aim of cancer therapy? Proc Soc Exp Biol Med. 1999;221(2):87-8. PMID: 10352117. Available from: 10.3181/ 00379727-221-44388.

22. Mahassni SH, Al-Reemi RM. Apoptosis and necrosis of human breast cancer cells by an aqueous extract of garden cress (Lepidium sativum) seeds. Saudi J Biol Sci. 2013;20(2):131-9. PMID: 23961228. Available from: 10.1016/j.sjbs.2012.12.002. 